Article

\title{
Fast and Efficient Method to Evaluate the Potential of Eutectic Solvents to Dissolve Lignocellulosic Components
}

\author{
Filipe H. B. Sosa ${ }^{1}{ }^{2}$, Rafael M. Dias ${ }^{1}$, André M. da Costa Lopes ${ }^{2}$, João A. P. Coutinho ${ }^{2}$ and \\ Mariana C. da Costa $1, *$ (D) \\ 1 School of Chemical Engineering (FEQ), University of Campinas (UNICAMP), Campinas, \\ São Paulo 13083-852, Brazil; filipesosa@ua.pt (F.H.B.S.); rafael.macedo.dias@hotmail.com (R.M.D.) \\ 2 CICECO, Aveiro Institute of Materials, Department of Chemistry, University of Aveiro, Aveiro 3810-193, \\ Portugal; andremcl@ua.pt (A.M.d.C.L.); jcoutinho@ua.pt (J.A.P.C.) \\ * Correspondence: mcdcosta@unicamp.br; Tel.: +55-19-3521-3962
}

Received: 3 April 2020; Accepted: 16 April 2020; Published: 20 April 2020

\begin{abstract}
The application of eutectic solvents (ESs) in lignocellulosic biomass fractionation has been demonstrated as a promising approach to accomplish efficient and environmentally friendly biomass valorization. In general, ESs are a combination of two components, a hydrogen-bonding donor and a hydrogen-bonding acceptor, in which the melting point of the mixture is lower than that of the individual components. However, there are plenty of possible combinations to form ESs with the potential to apply in biomass processing. Therefore, the development of fast and effective screening methods to find combinations capable to dissolve the main biomass components-namely cellulose, hemicelluloses, and lignin - is highly required. An accurate and simple technique based on optical microscopy with or without polarized lenses was used in this study to quickly screen and monitor the dissolution of cellulose, xylose (a monomer of hemicelluloses), and lignin in several ESs. The dissolution of these solutes were investigated in different choline-chloride-based ESs (ChCl:UREA, ChCl:PROP, ChCl:EtGLY, ChCl:OXA, ChCl:GLY, ChCl:LAC). Small amounts of solute and solvent with temperature control were applied and the dissolution process was monitored in real time. The results obtained in this study showed that cellulose was insoluble in these ESs, while lignin and xylose were progressively dissolved.
\end{abstract}

Keywords: optical microscopy; eutectic solvents; dissolution; cellulose; xylose; lignin; biomass

\section{Introduction}

Renewable resources such as lignocellulosic biomass have called the attention of the academic and industry communities because of their availability, low cost, and biodegradability. The use of lignocellulosic feedstock materials could lead to the development of more sustainable chemical processes as an alternative to the current exploitation of fossil-based resources [1]. In order to achieve this goal, the biorefinery concept which contemplates the fractionation and processing of lignocellulosic biomass components and their subsequent transformation into biofuels, biobased materials, and added-value chemicals should be promoted [2-4].

Lignocellulosic biomass is mostly composed of cellulose (35 wt\%-50 wt\%), hemicelluloses $(20 \mathrm{wt} \%-35 \mathrm{wt} \%)$, and lignin (5 wt\%-30 wt\%) [5], which are strongly bounded into an intricate solid matrix difficult to process and fractionate. Therefore, this recalcitrance should be overcome through the engagement of thermochemical [6], biological [7,8], or chemical processing platforms [9,10], allowing further fractionation and conversion into desired products. However, conventional processes require high temperature, non-ecofriendly solvents, and toxic and harmful reagents which directly impact economic viability and contravene environmental guidelines [11]. In addition, the reaction conditions 
applied in some processes can lead to degradation and/or reconditioning of hemicelluloses and lignin fractions, decreasing the sustainability of biomass exploitation [12].

Therefore, the development of environmentally safe processes for the dissolution and/or selective extraction of cellulose, hemicelluloses, and lignin from lignocellulosic materials is highly pursued. A promising alternative to achieve selective dissolution of these biopolymers is the application of eutectic solvents (ESs). This novel class of solvents is mixtures composed of at least one hydrogen-bonding acceptor (HBA) and one hydrogen-bonding donor (HBD) species, which establish stronger hydrogen bonds than those present in corresponding precursors, leading to significant depression of the melting temperature when compared to that of the individual compounds [13-16]. This example allows a mixture of two solids to be liquid at room temperature and act as a solvent for different solutes.

ESs have been studied in the development of new chemical processes because of their low volatility and good recyclability [14]. Furthermore, they can be prepared easily by a mild heating procedure, which can reduce costs and avoid the formation of undesirable secondary components [17]. In addition, ESs are easy to handle, since most of them do not form toxic substances when in contact with air and/or water [18]. Their physical, chemical, and thermal properties can be tuned by changing their precursors and their relative proportions, thus they are considered design solvents [19].

In recent years, the use of ESs has been reported in several research areas, such as electrodeposition [20], nanotechnology [21], biodiesel purification [22], and drugs dissolution [23]. More recently, they have been used in lignocellulosic biomass processing, including delignification, fractionation, and detoxification processes [24-26]. Although several studies have reported success using ESs in the fractionation of several biomass matrices, such as corn residues [27], corn straw [28], rice straw [29], woodchip [30], corn cob [31], and algae [32], there is still limited knowledge about their ability to dissolve each macromolecular component. There are some studies that focused on evaluating the dissolution ability of ESs for individual biomass components [24,29,33-36] and understanding the key factors governing the dissolution process [33,37-39]. For instance, Morais et al. [38] demonstrated that xylans can be solubilized in aqueous solutions of ESs. As proof of concept, further extraction of hemicelluloses from wood (Eucalyptus globulus) with a higher yield than that obtained with aqueous or alkaline solutions was accomplished successfully. In addition, the solubility of lignin model compounds and technical lignins (Organosolv and Kraft) in ESs and their aqueous solutions were studied by Soares et al. [33]. The authors showed that these solvents can act either as hydrotropes or as co-solvents [36] increasing lignin solubility.

The application of ESs in the fractionation of lignocellulosic biomass is still in its infancy and the screening of these solvents for the dissolution of each macromolecular component is highly required. Nevertheless, there are uncountable combinations of HBAs and HBDs that can mediate the formation of novel ESs that better dissolve one or another fraction of the biomass.

The use of COSMO-RS as a tool to verify the potential for dissolution of biomass fractions using ionic liquids (ILs) $[40,41]$ and ESs [42] is described in the literature. However, this procedure requires a precise definition of the solvent and solute and needs validation at the laboratory bench. Therefore, the development of quick screening techniques to choose new ESs for selective biomass dissolution is a valuable contribution.

The macroscopic inspection of cellulose, hemicelluloses, and/or lignin dissolution in different solvents has been reported broadly in the literature. For instance, this kind of approach was used by Swatloski et al. [43] in the determination of cellulose solubility in several aprotic ionic liquids (AILs) as well as by Pu et al. [44] in the screening of lignin dissolution in different ILs. However, this is a time-consuming procedure to screen the dissolution of solutes in a wide range of solvents. In this context, the use of optical microscopy to evaluate the dissolution process offers a quick response and more sensitivity, especially to cellulose and hemicelluloses, due to their birefringent nature [45]. Zavrel et al. [46] successfully used an optical microscope without temperature control to monitor the dissolution of cellulose in 1-ethyl-3-methylimidazolium acetate over time. In other work, Fitzpatrick et al. [45] used an optical microscope with temperature control to screen the dissolution of cellulose 
and lignin in two imidazolium-based ILs. The researchers demonstrated that optical microscopy in the presence or absence of cross-polarized lenses can be used for a fast screening and monitoring of cellulose and/or lignin dissolution in a wide range of ILs and non-IL solvents, using small amounts of solvent and solute. Similarly, Andanson et al. [47] studied the cellulose dissolution in ILs and mixtures of ILs + dimethylsulfoxide from 30 to $100{ }^{\circ} \mathrm{C}$ using a synthetic phase equilibrium method based on polarized optical microscopy (POM). The authors measured the brightness of the microscope images, which was used to qualitatively assess the biopolymer dissolution process. More recently, Dias and coworkers $[48,49]$ evaluated the potential of protic ionic liquids (PILs) to dissolve major lignocellulosic components using POM.

In this study, the dissolution of cellulose, alkaline lignin, and xylose (one of the main units in hemicelluloses) in different ESs based on choline chloride (ChCl:UREA (1:2), ChCl:PROP (1:2), ChCl:EtGLY (1:2), ChCl:OXA (1:1), ChCl:GLY (1:2), ChCl:LAC (1:2)) was investigated through POM (cellulose and xylose) or simple optical microscopy (lignin), both with temperature control. This methodology was used as a fast screening approach to rapidly evaluate the dissolution of those solutes and their kinetics rather than performing a macroscopic observation.

\section{Materials and Methods}

\subsection{Chemicals}

Microcrystalline cellulose (MCC) Avicel ${ }^{\circledR}$ PH-101 ( 50 $\mu \mathrm{m}$ particle size, $\geq 99 \%$ ), $\alpha$-cellulose (powder, $\geq 99 \%$ ), lignin-alkali (>96\%) and D-(+)-xylose ( $\geq 99 \%$ ) were purchased from Sigma-Aldrich (St. Louis, MO, USA); ethylene glycol ( $\geq 99 \%$ ) from Merck (Darmstadt, Germany), urea ( $\geq 99 \%)$ and glycerol ( $\geq 99 \%$ ) from Anidrol (Diadema, Brazil), 1,3-propanediol ( $\geq 9 \%$ ) from Acros (Geel, Belgium), oxalic acid $(\geq 99 \%)$ from Scharlau (Barcelona, Spain). All these reactants were used as received. Lactic acid ( $\geq 85 \%)$ from Aldrich (Darmstadt, Germany) and choline chloride ( $\geq 98 \%$ ) from Sigma-Aldrich were previously dried using rotary evaporator $\left(60^{\circ} \mathrm{C}\right.$ and $70.0 \mathrm{~Pa}$ absolute pressure) for $24 \mathrm{~h}$ and maintained in a glass desiccator with silica gel until its use. Table 1 presents the chemical structures of HBD and quaternary ammonium salt (HBA) used to prepare the ESs.

\subsection{Eutectic Solvents Preparation}

According to Table 1, ESs were prepared in molar ratios of choline chloride to HBDs using a mild heating procedure, i.e., the precursors were stirred at $60{ }^{\circ} \mathrm{C}$ for $2 \mathrm{~h}$ or until a homogeneous transparent liquid was formed [14]. The ESs' water content was measured by Karl Fischer (Karl Fischer Titrino Plus 848, Metrohm, Herisau, Switzerland) and ranged from $2 \mathrm{wt} \%$ to $5 \mathrm{wt} \%$ as reported in Table S1 (Supplementary Material—SM).

\subsection{Thermogravimetric Analysis (TGA)}

ES thermal decomposition temperatures were determined by a TGA/DSC Mettler Toledo (Schwerzenbach, Switzerland). The equipment was heated at a rate of $10^{\circ} \mathrm{C} \cdot \mathrm{min}^{-1}$ in a temperature range of $30-500{ }^{\circ} \mathrm{C}$. Approximately $5 \mathrm{mg}$ of the samples were carefully placed in an aluminum pan and the samples were analyzed under nitrogen atmosphere using a flow rate of $50 \mathrm{~mL} \mathrm{~min}^{-1}$.

\subsection{Dissolution of Solutes by Polarized Optical Microscopy or Simple Optical Microscopy}

The dissolution of MCC, $\alpha$-cellulose, alkaline lignin, and xylose in ES was studied by implementing a method based on optical microscopy [47]. The experimental procedure to observe the dissolution process was similar to that reported by Andanson et al. [47]. First, an ES/solute suspension (500 mg) was prepared by shaking vigorously. Afterward, approximately $50 \mathrm{mg}$ suspension was dropped in a glass coverslip that was laid down on the heating plate (Linkam LTS420, Surrey, UK) of the optical microscope (Leica DM2700M, Wetzlar, Germany) preheated to $30.0^{\circ} \mathrm{C}$. The sample was heated from 30.0 to $100.0^{\circ} \mathrm{C}$ at $1.0^{\circ} \mathrm{C} \cdot \mathrm{min}^{-1}$ and an image $(2048 \times 1536$ pixels $)$ was captured at each minute. 
Table 1. The hydrogen-bonding acceptor (HBA) and hydrogen-bonding donor (HBD) precursors used in this work to prepare eutectic solvents (ESs).

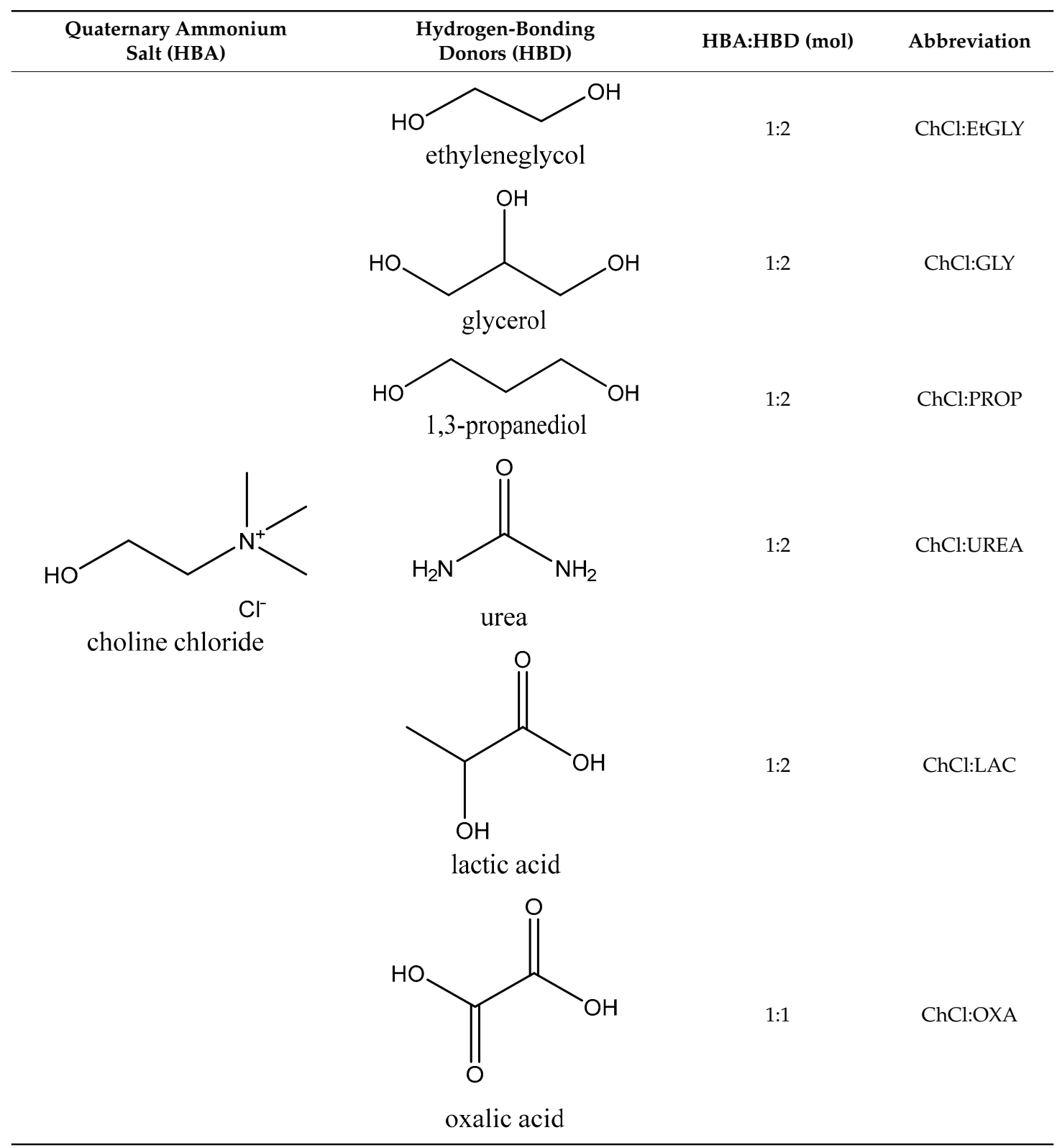

The dissolution changes in cellulose and xylose were monitored by polarized optical microscopy (POM) using two polarizing filters, which are specifically sensitive to these solutes. A dark background appeared in the microscope images representing the ES as liquid phase, while cellulose and xylose behaved as birefringent materials. When placed between two polarized lenses, both solutes were illuminated. If the solutes dissolved in ES, the bright areas decrease over the experiment.

In lignin dissolution tests, optical microscopy without polarized lenses was used, since lignin macromolecules are not sensitive to polarized light. In this configuration, the lignin was observed as dark spots in the microscope images, while the light areas corresponded to the ES liquid phase. During the experiment, the background became red as consequence of lignin dissolution in ES.

The overall mass composition used in this work is given by the following equation:

$$
\mathrm{wt} \%=100 * m_{\text {solute }} /\left(m_{\text {solute }}+m_{E S}\right)
$$




\subsection{Dissolution Kinetics of Xylose}

The kinetics of xylose dissolution was also evaluated through Image Pro-Premier ${ }^{\circledR}$ software (v.9.2, Media Cybernetics, Berkshire, UK), which allowed quantifying the area occupied by the crystals as function of temperature increase and time course as follows:

$$
\text { Crystal area }(\%)=\left(\text { area }_{t} / \text { area }_{t 0}\right) * 100
$$

where area $a_{t}$ represents the total area of the crystals at selected time and area ${ }_{t 0}$ represents the total area of the crystals at initial time.

Image-Pro Premier ${ }^{\circledR}$ software was also used for image processing to highlight points of interest and allow optimization of the area filled by crystals. In some cases, fluctuations in the values of total area of the crystals were observed and it can be attributed to gaseous bubbles (larger, rounded, and darker particles) created during dissolution or to the overlapping of xylose crystals reducing the image brightness and consequently the calculated crystal area.

\section{Results}

In order to avoid any misunderstanding concerning the nomenclature used in this work, it is important to emphasize that the term "solubility" refers to the ability of a solvent to dissolve a solute under specific environmental conditions. Solubility is a thermodynamic process in which the system evolves to reach a point of lowest Gibbs energy as the most stable thermodynamically [46]. Therefore, it is understood as an equilibrium state, where the solute is dissolved by a solvent and is independent of the speed at which the phenomenon takes place. On the other hand, the term "dissolution" concerns a kinetic process that is not necessarily synonymous with solubility, since dissolution might be fast, but low amount of solute could be dissolved. Bearing all this in mind, this last term was tackled in this study.

Before performing the dissolution experiments, the thermal stability of all ESs studied in this work was determined. The results obtained with TGA (Figure S1) showed an ES mass loss between 100 and $150{ }^{\circ} \mathrm{C}$. Therefore, the dissolution experiments were performed at temperatures lower than $100^{\circ} \mathrm{C}$ to assure no ES mass loss and consequently no solvent decomposition over time for a proper screening.

\section{1. $\alpha$-cellulose and Microcrystalline Cellulose Dissolution}

Dissolution of two cellulose standards, $\alpha$-cellulose and microcrystalline cellulose (MCC), was monitored in six different ESs (ChCl:UREA, ChCl:PROP, ChCl:EtGLY, ChCl:OXA, ChCl:GLY, $\mathrm{ChCl}: \mathrm{LAC})$ through the POM technique. Characteristic images of the dissolution process with $\mathrm{ChCl:GLY}$ and $\mathrm{ChCl}: \mathrm{UREA}$ were captured at the initial temperature $\left(30.0^{\circ} \mathrm{C}\right)$ and at the final temperature $\left(100.0^{\circ} \mathrm{C}\right)$, as shown in Figure 1 as examples. The colored areas correspond to insoluble cellulose (solid), while the dark space corresponds to the ES as a liquid phase. Images captured for other tested ESs are presented in the SM (Figure S2).

The obtained results showed no significant change between $30.0^{\circ} \mathrm{C}$ and $100{ }^{\circ} \mathrm{C}$, i.e., the area occupied by cellulose crystals/fibers remained practically unchanged during the dissolution process, demonstrating that none of the studied ESs is able to dissolve $\alpha$-cellulose or MCC ( $1 \%$ by weight) under the analyzed conditions. In order to corroborate these results, a solution of $0.25 \mathrm{wt} \% \alpha$-cellulose and a solution of $0.25 \mathrm{wt} \% \mathrm{MCC}$ were kept under stirring for $48 \mathrm{~h}$ at $60{ }^{\circ} \mathrm{C}$ in a ChCl:GLY solution (out of the microscope) to reach the equilibrium. After this time, samples were collected and observed by POM. MCC and $\alpha$-cellulose were clearly observed in the ChCl:GLY solution after $48 \mathrm{~h}$ at $60^{\circ} \mathrm{C}$ (Figure S3), confirming the inability of ChCl:GLY to solubilize cellulose.

The low solubility of cellulose in most of the existing solvents relies on the strong intra- and intermolecular interactions between cellulose chains that offer a high degree of crystallinity and ordered conformation [50-52]. The dissolution of cellulose involves the disruption of that network of interactions and replacement with new intermolecular bonds established by the solvent. In this sense, 
if the intermolecular forces of cellulose-cellulose interactions are bigger than that existing between cellulose and solvent, no dissolution will be carried out [52-54].
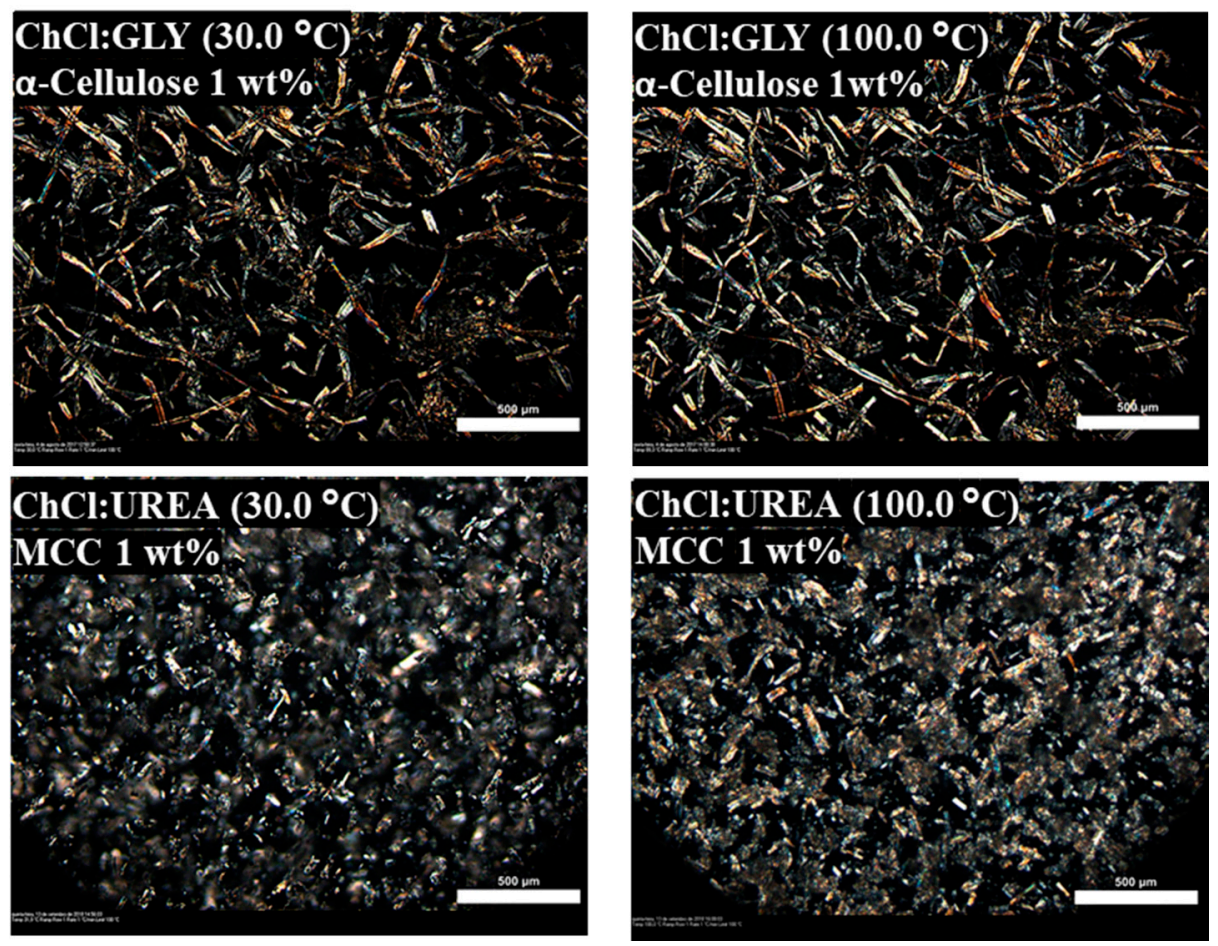

Figure 1. Polarized optical microscope images of $1 \mathrm{wt} \%$ cellulose in $\mathrm{ES}$ at $1.0^{\circ} \mathrm{C} \cdot \mathrm{min}^{-1}$ (magnification of 50×). MCC-microcrystalline cellulose.

In the literature, an extensive number of ionic liquids (ILs) have been reported to dissolve cellulose, explained by their ability to disrupt the strong hydrogen bond network of cellulose mediated by both cationic and anionic species of the solvent. In fact, the high hydrogen-bond basicity of the anion (e.g., chloride and acetate) was referred to play a major role in the dissolution process [9,50,52,54-57]. In the case of ESs, the obtained results allowed us to conclude that selected ESs were not able to break up the intra- and intermolecular network of cellulose and alter its crystalline arrangements. This is also reported in other studies, which demonstrated that MCC and $\alpha$-cellulose are poorly soluble in ESs $[19,24,58,59]$. Recently, Abbott and his co-worker Häkkinen explained possible differences between ESs' and ILs' abilities of cellulose dissolution [60]. The superior solubility of cellulose in some ILs was correlated with their highly ordered structure. This allows for enhanced solubility of the macromolecule in ILs as a consequence of a greater degree of disorder in the system, i.e., an entropy gain. On the other hand, the lower order conformation of ESs hinders the entropy gain of the solvent, resulting in lower cellulose solubility [61].

\subsection{Alkaline Lignin Dissolution}

Contrary to cellulose dissolution trials, the lignin dissolution in ES was evaluated by simple optical microscopy, since no birefringence property is exhibited by lignin macromolecules. Figure 2 shows the images captured during the alkaline lignin dissolution process in ChCl:EtGLY and ChCl:LAC at a heating rate of $1^{\circ} \mathrm{C} \cdot \mathrm{min}^{-1}$. The images presented in the first column (initial time-t0) show the undissolved lignin as dark solid agglomerates and the yellowish areas exhibit the ES as a liquid phase with traces of dissolved lignin. During the experiment, as the temperature increased the ES phase became reddish due to the alkaline lignin dissolution. Consequently, the number of dark spots substantially decreased (intermediate time between $\mathrm{t} 1$ and $\mathrm{t} 2$ ). The stronger tones of red were observed only for solutions with high lignin mass fractions, for example at $25 \mathrm{wt} \%$. Furthermore, some images 
presented abnormal remaining dark spots (marked with red circles in Figure 2) and were identified as gaseous bubbles initially retained and released during the heating method [45,47]. The identification of gaseous bubbles instead of lignin can be performed because of their round shape with a bright circle in the middle, which is noticeably different from the lignin dark agglomerates observed at lower temperatures. These bubbles were also observed by Fitzpatrick et al. [45] as well as reported in a previous study using protic ILs to dissolve lignin [48].
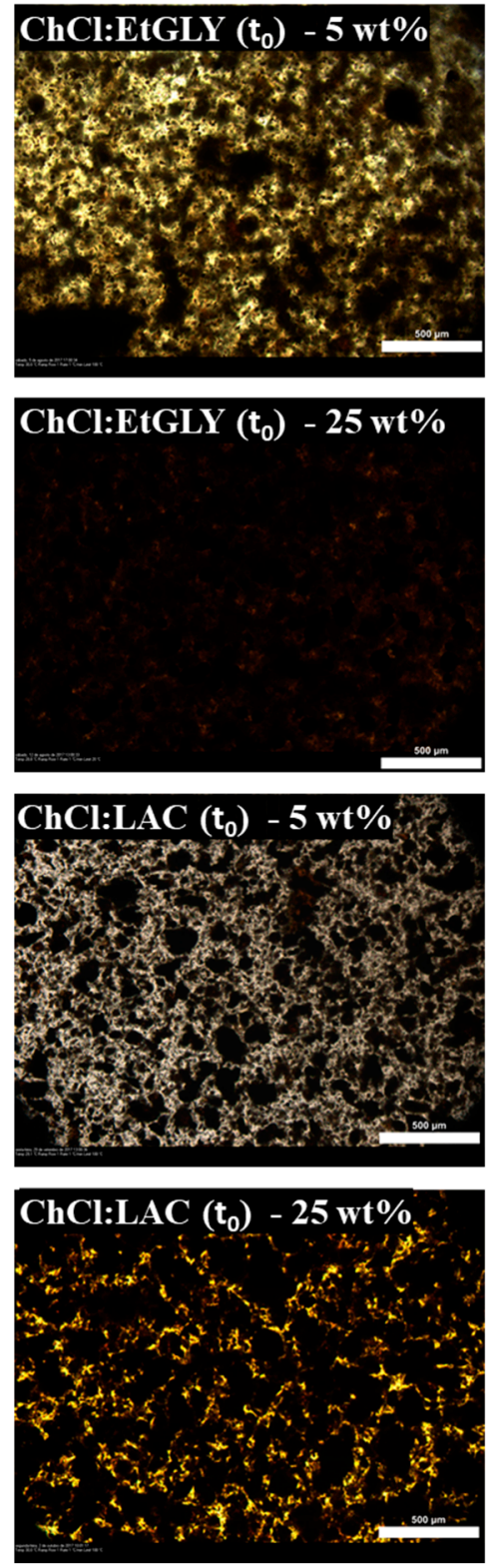
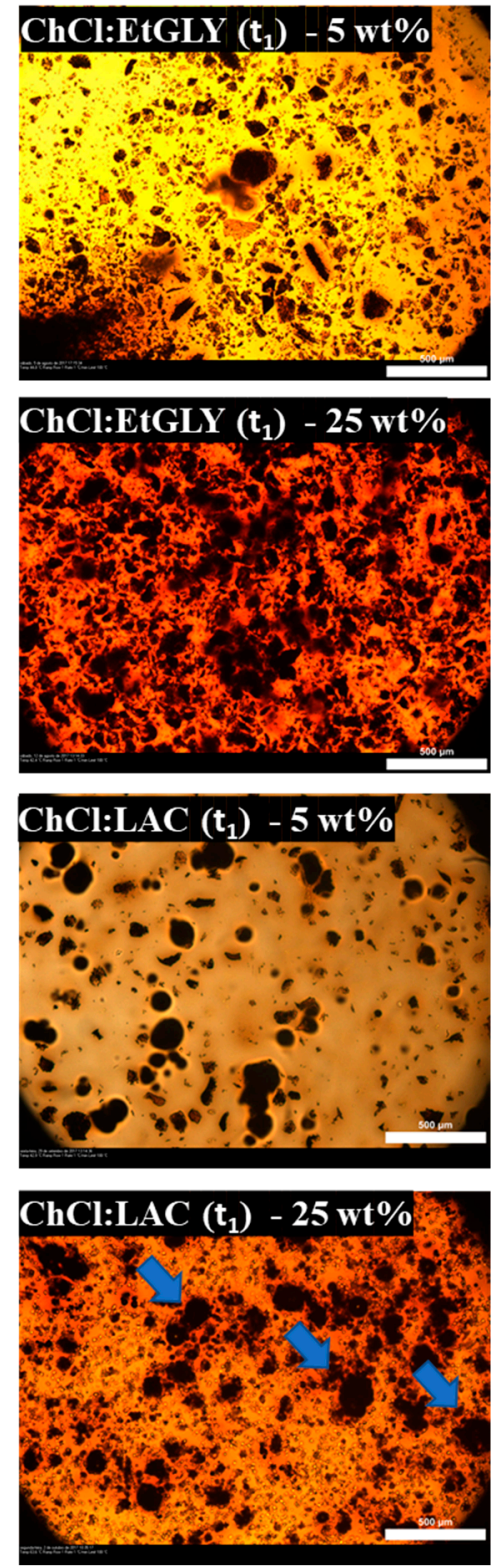
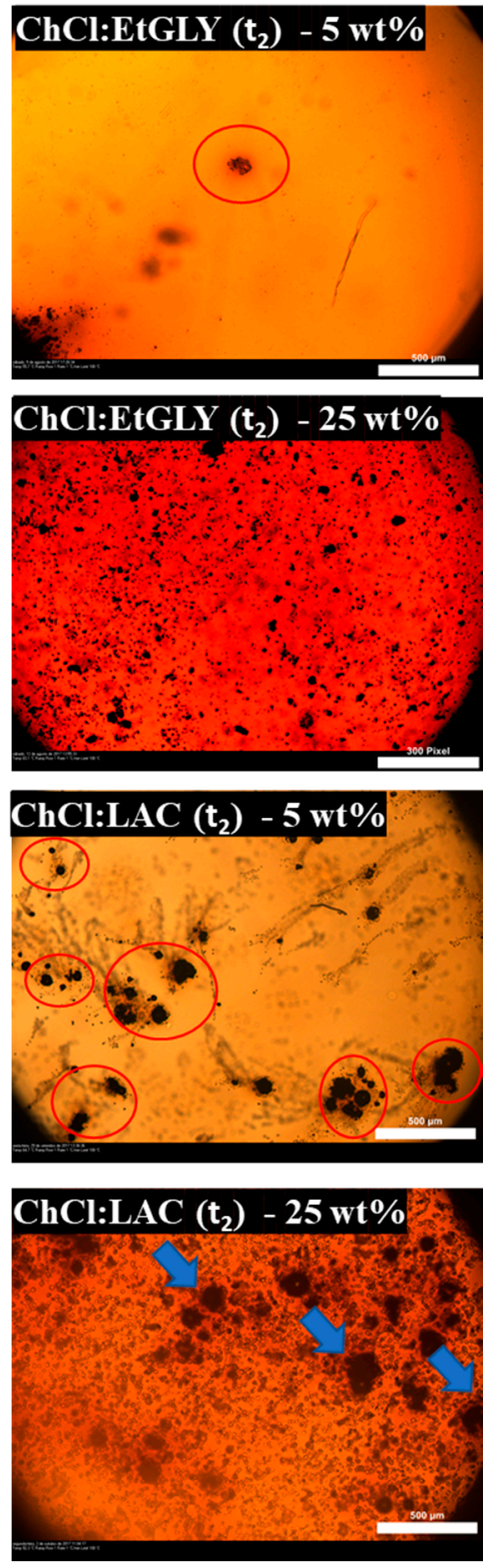

Figure 2. Optical microscope images of $5 \mathrm{wt} \%$ and $25 \mathrm{wt} \%$ of alkaline lignin in $\mathrm{ES}$ at $1{ }^{\circ} \mathrm{C} \cdot \mathrm{min}^{-1}$ (magnification of $50 \times$ ).

According to the images presented in Figure 2, ChCl:EtGLY demonstrated a high ability for alkaline lignin dissolution, while $\mathrm{ChCl}$ :LAC was less efficient. In addition to gaseous bubbles, this last ES presented a large number of agglomerates (highlighted with the blue arrows in Figure 2) indicating incomplete lignin dissolution. The images of alkaline lignin dissolutions with other ESs can be seen in the SM (Figures S4 and S5).

Table 2 summarizes the temperature and time at which complete alkaline lignin dissolution was achieved in each ES at different lignin mass fractions. The ESs' dissolution abilities can be organized in 
the following order: $\mathrm{ChCl}$ :EtGLY $\gg \mathrm{ChCl}$ OXA $\cong \mathrm{ChCl}: \mathrm{LAC}>\mathrm{ChCl}: \mathrm{UREA}>\mathrm{ChCl}: \mathrm{GLY}>\mathrm{ChCl}: \mathrm{PROP}$. A comparative graph between each ES and the temperature and time to achieve complete alkaline lignin dissolution are presented in the SM (Figure S8).

Table 2. Temperature (and time) required to dissolve alkaline lignin completely in ES at different lignin mass fractions. The samples were heated from 30 to $100{ }^{\circ} \mathrm{C}$ at $1^{\circ} \mathrm{C} \cdot \mathrm{min}^{-1}$.

\begin{tabular}{|c|c|c|c|c|c|c|c|c|c|c|}
\hline \multirow{2}{*}{ ES } & \multicolumn{2}{|c|}{$5 \mathrm{wt} \%$} & \multicolumn{2}{|c|}{$10 w t \%$} & \multicolumn{2}{|c|}{$15 w t \%$} & \multicolumn{2}{|c|}{$20 w t \%$} & \multicolumn{2}{|c|}{$25 w t \%$} \\
\hline & $\mathrm{T}\left({ }^{\circ} \mathrm{C}\right)$ & $t(\min )$ & $\mathrm{T}\left({ }^{\circ} \mathrm{C}\right)$ & $t(\min )$ & $\mathrm{T}\left({ }^{\circ} \mathrm{C}\right)$ & $t(\min )$ & $\mathrm{T}\left({ }^{\circ} \mathrm{C}\right)$ & $t(\min )$ & $\mathrm{T}\left({ }^{\circ} \mathrm{C}\right)$ & $t$ (min) \\
\hline ChCl:GLY & 58.6 & 28.6 & 66.5 & 36.5 & 84.4 & 54.4 & * & * & * & * \\
\hline ChCl:EtGLY & 50.8 & 20.8 & 56.6 & 26.5 & 63.5 & 33.5 & 68.7 & 38.7 & 77.1 & 47.1 \\
\hline ChCl:PROP & 91.4 & 61.4 & $*$ & $*$ & $*$ & $*$ & * & * & $*$ & $*$ \\
\hline ChCl:UREA & 80.4 & 50.5 & 84.4 & 54.4 & 91.3 & 61.3 & 100 & 70 & * & * \\
\hline ChCl:LAC & 50.8 & 20.8 & 57.6 & 27.6 & 71.5 & 41.5 & 86.5 & 56.5 & * & * \\
\hline ChCl:OXA & 49.6 & 19.6 & 59.5 & 29.5 & 72.6 & 42.6 & 82.4 & 52.4 & * & * \\
\hline
\end{tabular}

In general, the dissolution of lignin in a solvent involves disrupting $\pi-\pi$ stacking interactions between lignin aromatic groups and establishing strong intermolecular hydrogen bonds with hydrogen bond acceptor and donor groups (e.g., hydroxyl groups) in lignin structure [62,63]. In this context and by taking a close look at the obtained data, it can be observed that the chemical structure of HBDs plays an important role in alkaline lignin dissolution. Among examined ESs, ChCl:EtGLY exhibited the best performance for alkaline lignin dissolution, especially at high lignin mass fractions. This could be associated with the synergy between the small size and the two hydroxyl groups of EtGLY allowing for higher diffusion and stronger ability to form hydrogen bonds with lignin than in the cases of LAC, UREA, GLY, and PROP. Melro et al. [64] and Soares et al. [33] also demonstrated that EtGLY as an HBD has better lignin dissolution performance compared to simple alcohols, due to the presence of two HBD sites. Although GLY presents one more hydroxyl group than EtGLY, the high viscosity of the former might hinder the mass transfer during lignin dissolution decreasing the performance of ChCl:GLY.

\subsection{Xylose Dissolution}

The xylose dissolution in ESs was studied by the POM technique and the obtained results with $\mathrm{ChCl}: U R E A$ and $\mathrm{ChCl}$ OXA are presented in Figure 3 as examples. More images of other ESs are presented in the SM (Figures S6 and S7). In Figure 3, the clear area corresponds to undissolved xylose crystals, which disappear over time, while the dark area represents the ES (liquid phase). The complete dissolution is observed when no clear area is detected, or in other words, when the image is completely dark. Two mass fractions of xylose ( $5 \mathrm{wt} \%$ and $25 \mathrm{wt} \%$ ) were applied in the dissolution trials and it can be observed that the higher the concentration of xylose, the higher the number of crystals visualized in the images (Figure 3).

Considering the temperature of total dissolution of xylose in ES, i.e., when the obtained image is completely dark, the efficiency of the tested ES to dissolve xylose can be evaluated. The temperatures of the complete dissolution of xylose at initial mass fractions of $5 \mathrm{wt} \%$ and $25 \mathrm{wt} \%$ are shown in Figure 4 (also in Table S2 in the SM). At $5 \mathrm{wt} \%$ xylose, the efficiency of the ESs can be ordered as follows: ChCl:EtGLY $\left(46.9^{\circ} \mathrm{C}\right) \gg \mathrm{ChCl}$ :PROP $\left(57.7^{\circ} \mathrm{C}\right)>\mathrm{ChCl}$ :GLY $\left(59.2^{\circ} \mathrm{C}\right) \cong \mathrm{ChCl}$ :UREA $\left(59.6^{\circ} \mathrm{C}\right)$ $>\mathrm{ChCl}$ :OXA $\left(61.5^{\circ} \mathrm{C}\right) \gg \mathrm{ChCl}$ :LAC $\left(80.3^{\circ} \mathrm{C}\right)$. However, at a higher xylose mass fraction $(25 \mathrm{wt} \%)$, a different trend was observed. $\mathrm{ChCl}$ :UREA $\left(83.3^{\circ} \mathrm{C}\right)$ was the fastest $\mathrm{ES}$ to dissolve all xylose content, while other ESs needed more time to reach the same point (between 90 and $100{ }^{\circ} \mathrm{C}$ ). On the other hand, $\mathrm{ChCl}$ :LAC did not achieve total xylose dissolution. 

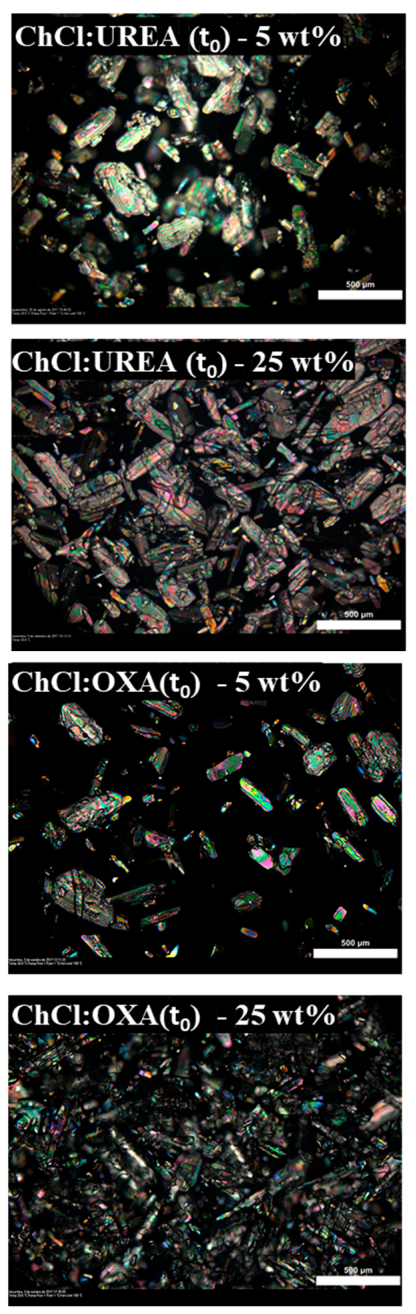
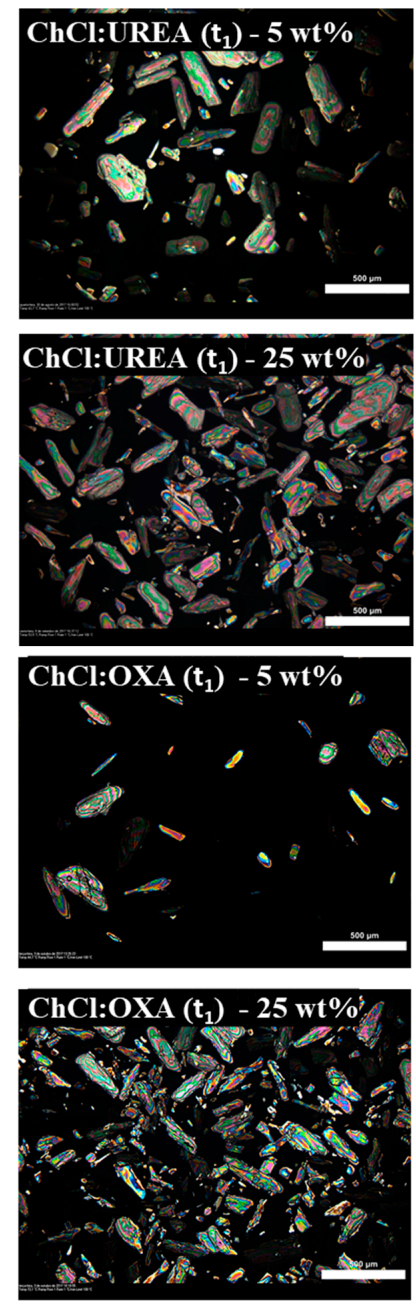
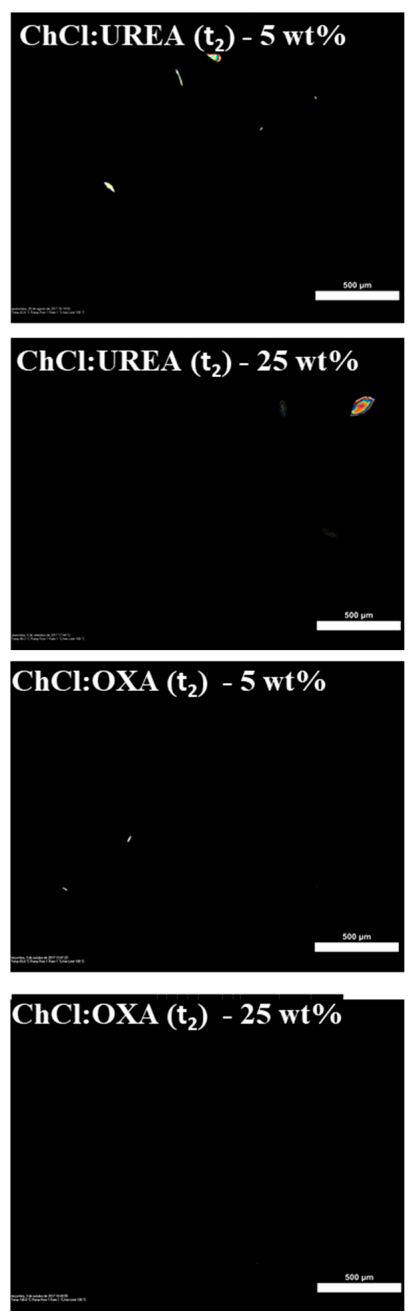

Figure 3. Polarized optical microscope images of $5 \mathrm{wt} \%$ and $25 \mathrm{wt} \%$ xylose in ES at $1{ }^{\circ} \mathrm{C} \cdot \mathrm{min}^{-1}$ (magnification of $50 \times$ ). $t_{0}$ represent the initial time, $t_{1}$ represent the intermediate time and $t_{2}$ the final time.

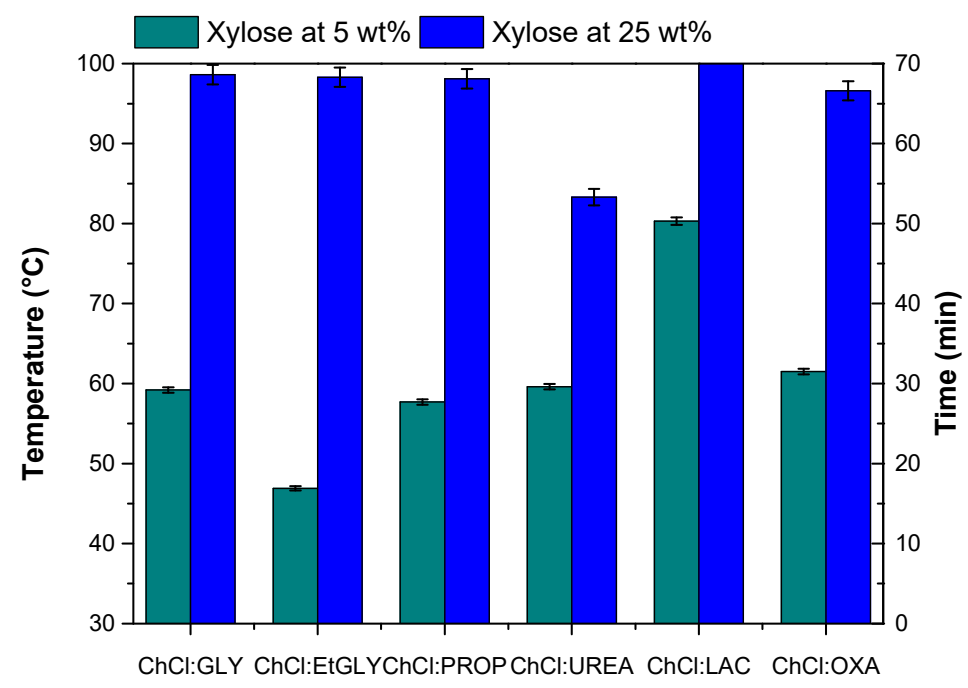

ES

Figure 4. Temperature and time required for xylose full dissolution in ES. The samples were heated from 30 to $100{ }^{\circ} \mathrm{C}, 1{ }^{\circ} \mathrm{C} \cdot \mathrm{min}^{-1}$. Full xylose dissolution was not observed. 
These intriguing results led us to go deeper into this analysis and the kinetics of xylose dissolution in ESs at different xylose mass fractions were determined. In this sense, Image-Pro Premier ${ }^{\circledR}$ software was used as a tool to determine the total area of the xylose crystals over the course of the dissolution trials. This data allowed us to obtain the results depicted in Figure 5 showing the decrease of the total area of xylose crystals as a function of temperature and time in each ES at different xylose mass fractions ( $5 \mathrm{wt} \%, 10 \mathrm{wt} \%, 15 \mathrm{wt} \%, 20 \mathrm{wt} \%$, and $25 \mathrm{wt} \%$ ).
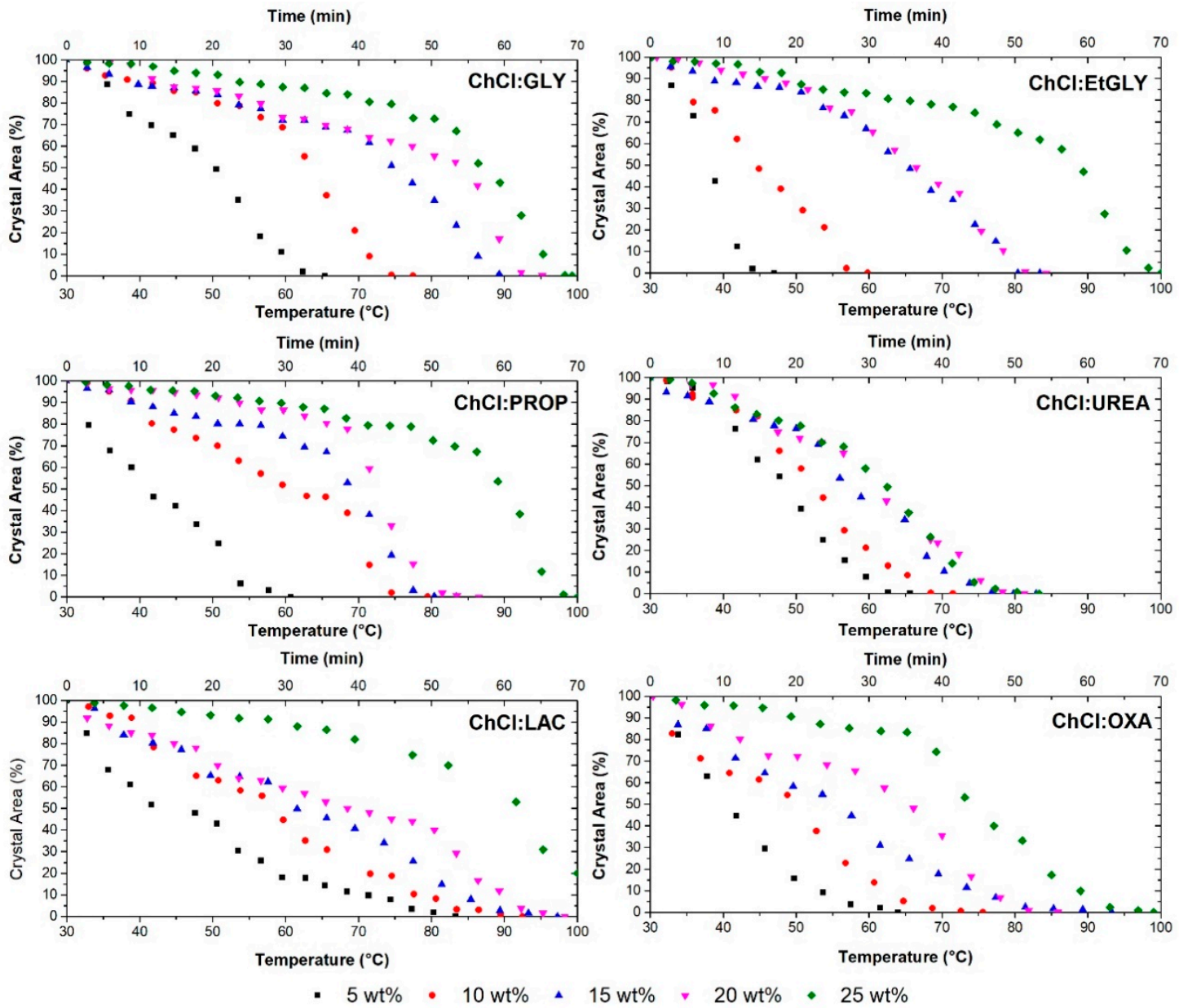

Figure 5. Dissolution kinetics of xylose at different mass fractions $(5 \mathrm{wt} \%, 10 \mathrm{wt} \%, 15 \mathrm{wt} \%, 20 \mathrm{wt} \%$, and $25 \mathrm{wt} \%$ ) in ChCl:GLY, ChCl:EtGLY, ChCl:PROP, ChCl:UREA, ChCl:LAC, ChCl:OXA at $1^{\circ} \mathrm{C} \cdot \mathrm{min}^{-1}$ in a temperature range from 30 to $100{ }^{\circ} \mathrm{C}$.

Surprisingly, the dissolution behavior of ESs demonstrated different trends depending on the initial xylose mass fraction. At 5\% xylose mass fraction, ESs prepared with alcohols (ChCl:EtGLY, $\mathrm{ChCl}: \mathrm{GLY}, \mathrm{ChCl}$ :PROP) presented a fast xylose dissolution rate demonstrating the best performance among all. However, when increasing the xylose mass fraction, these alcohol-based ESs exhibited low xylose dissolution rates at initial stages evidenced by the plateau of the xylose crystal area during the experiment (Figure 4). Only at high temperatures did the dissolution rate substantially increase. For example, ChCl:EtGLY at $25 \mathrm{wt} \%$ xylose mass fraction showed a low dissolution rate $\left(0.40\right.$ area $\left.\% \cdot \mathrm{min}^{-1}\right)$ up to $74{ }^{\circ} \mathrm{C}(44 \mathrm{~min})$, in which around $25 \%$ of the crystals were dissolved. After this point, the dissolution rate increased sharply $\left(1.21 \mathrm{area} \% \cdot \mathrm{min}^{-1}\right)$ and the remaining amount of xylose crystals (about 75\%) were completely dissolved in less than $25 \mathrm{~min}$. Taking into account the factors affecting the dissolution process, a decrease of the xylose surface area provided by the higher amount of the carbohydrate in the system may have hindered the interactions with the solvent. This explains the difficulty of those ESs to dissolve xylose at high mass fractions. Furthermore, 
a higher number of solute-solute interactions that are competing with those between solute and solvent are expected to occur. However, this "resistance" to dissolve xylose was not the same for all studied ESs. The xylose dissolution rates in carboxylic-acid-based ESs (ChCl:OXA and ChCl:LAC) varied depending on the xylose mass fractions, but the differences between those trends were lower than those of alcohol-based ES. These differences were even lower for $\mathrm{ChCl}$ :UREA, which was quicker to achieve complete carbohydrate dissolution at the highest xylose mass fraction ( $25 \mathrm{wt} \%)$. In systems where no agitation was promoted, the dissolution was highly dependent on the ability of ESs to interact with the carbohydrate (surface area) with temperature increase. Somehow, ChCl:UREA allowed better dispersion of xylose crystals than other ESs surpassing the solute-solute interactions at high xylose mass fractions. The high performance of $\mathrm{ChCl}$ :UREA for xylose dissolution in this study is in agreement with the results reported by Morais et al. [38] reporting the highest xylan solubility in this ES.

Seeking to better understand the results obtained with the dissolution kinetics, the average mass transfer coefficient $(\mathrm{kc})$ of xylose in each of the different ESs was calculated using the methodology described in the SM (Section S5). The obtained results are presented in Figure 6 and are expressed as pixel. $\mathrm{s}^{-1}$.

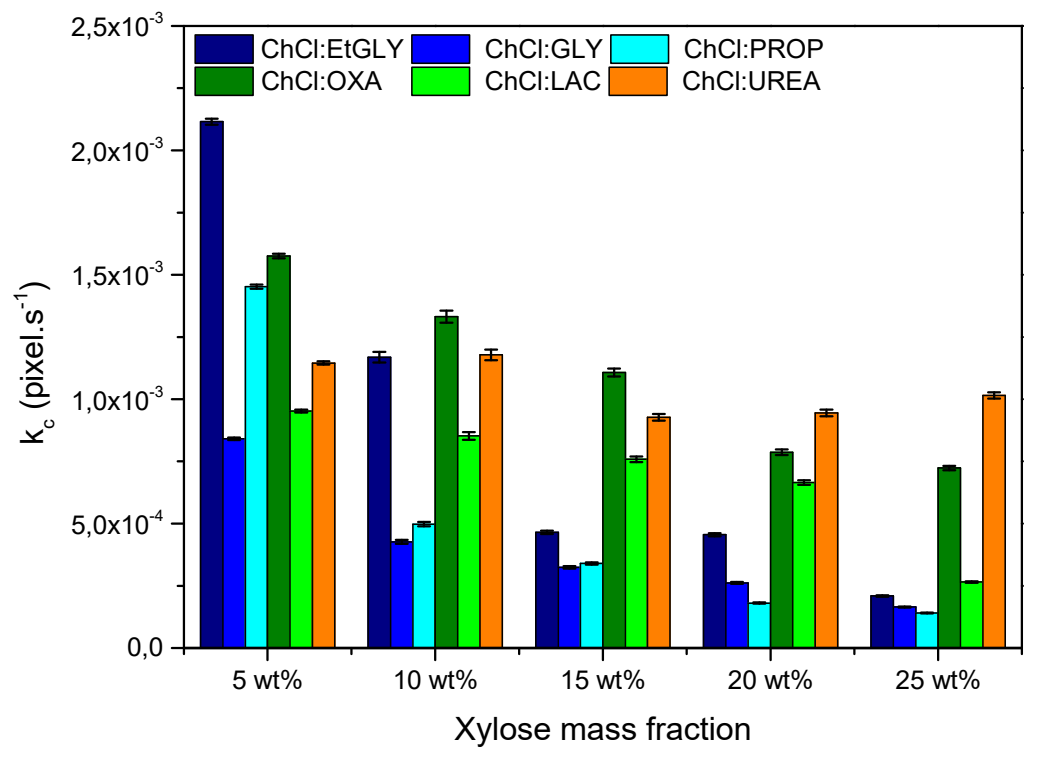

Figure 6. Mass transfer coefficient estimated for different ESs at initial xylose mass fractions of $5 \mathrm{wt} \%$, $10 w t \%, 15 w t \%, 20 w t \%, 25 w t \%$.

At first sight, the alcohol-based ESs at $5 \mathrm{wt} \%$ xylose presented the highest average mass transfer coefficients. For instance, $\mathrm{ChCl}$ :EtGLY exhibited a kc value of $2.12 \times 10^{-3} \mathrm{pixel} \cdot \mathrm{s}^{-1}$. On the other hand, lower kc values were determined for carboxylic-acid-based ESs, namely $1.58 \times 10^{-3}$ and $9.52 \times 10^{-4}$ pixel $\cdot \mathrm{s}^{-1}$ for $\mathrm{ChCl}$ :OXA and ChCl:LAC, respectively. With increasing xylose mass fraction in ESs, the calculated kc values displayed a decreasing trend (Figure 6). This behavior was more pronounced in alcohol-based ESs. In the case of ChCl:PROP, a value of $\mathrm{kc}=1.45 \times 10^{-3} \mathrm{pixel} \cdot \mathrm{s}^{-1}$ was determined at $5 \mathrm{wt} \%$ xylose, while at $25 \mathrm{wt} \%$ xylose a value of $\mathrm{kc}=1.41 \times 10^{-4}$ pixel. $\mathrm{s}^{-1}$ was found, which represents a decrease of approximately an order of magnitude. In addition, the kc values for $\mathrm{ChCl}$ :OXA decreased 2-fold between $5 \mathrm{wt} \%$ and $25 \mathrm{wt} \%$ xylose mass fraction in ES.

Regardless of the initial xylose mass fraction, the experiments with $\mathrm{ChCl}$ :UREA showed regular values, i.e., the $\mathrm{kc}$ value determined for this ES at $5 \mathrm{wt} \%$ xylose $\left(1.15 \times 10^{-3} \mathrm{pixel} \cdot \mathrm{s}^{-1}\right)$ was similar to that found at $25 \mathrm{wt} \%$ xylose $\left(1.02 \times 10^{-3} \mathrm{pixel} \cdot \mathrm{s}^{-1}\right)$. This supports the idea that mass transfer limitations might be avoided when using $\mathrm{ChCl}$ :UREA as a solvent to dissolve xylose (and expectably xylan).

This data also led us to conclude that the HBD's chemical nature (alcohol, carboxylic acid, or carbamide) of ES influenced the dissolution process of xylose. Therefore, the barrier found to dissolve high amounts of xylose is not only governed by the competition of interactions between 
solute-solute and solute-solvent, but also by the chemical properties of the HBD, since the dissolution behavior observed between the different groups of ESs was not similar.

\section{Conclusions}

A fast screening of cellulose, alkaline lignin, and xylose dissolutions in ChCl:UREA, ChCl:PROP, $\mathrm{ChCl}: \mathrm{EtGLY}, \mathrm{ChCl}$ :OXA, ChCl:GLY, ChCl:LAC was herein demonstrated by using an optical microscope with or without polarized lenses. It is a versatile technique, requires small amounts of sample and solvent, and the results are acquired quite fast. Two kinds of cellulose were used ( $\alpha$-cellulose and microcrystalline cellulose) and both demonstrated to be insoluble in examined ESs. Regarding the alkaline lignin dissolution in our study, the ability of ESs can be ordered as follows: ChCl:EtGLY $\gg \mathrm{ChCl}: \mathrm{OXA} \cong \mathrm{ChCl}$ :LAC $>\mathrm{ChCl}$ :UREA $>\mathrm{ChCl}: \mathrm{GLY}>\mathrm{ChCl}$ :PROP. The small size and the two hydroxyl groups of EtGLY may enable strong interactions with lignin allowing high performance in the dissolution process. In respect to xylose dissolution trials, although ChCl:EtGLY demonstrated the fastest dissolution at $5 \mathrm{wt} \%$ xylose, this ES showed difficulties to dissolve higher mass fractions of the carbohydrate, due to mass transfer limitations. In this context, ChCl:UREA was revealed to be a better solvent for xylose by practically maintaining the dissolution performance with an increasing carbohydrate mass fraction.

All these data give some insights into potential ESs that can be applied for biomass processing and valorization. However, it is important to point out that these results serve as a preliminary evaluation, since the capacity of these solvents to extract components, such as lignin and hemicelluloses (e.g., xylans), from biomass relies not only on their dissolution ability, but also on their reactivity to cleave covalent bonds existing between biomass macromolecular components.

Supplementary Materials: The following are available online at http://www.mdpi.com/2071-1050/12/8/3358/s1, Figure S1: Thermogravimetric analysis (TGA) thermograms of studied ES, Figure S2: Images obtained by polarized optical microscopy of $1 \mathrm{wt} \%$ cellulose in ES at heating rate of $1{ }^{\circ} \mathrm{C} \cdot \mathrm{min}^{-1}$ (magnification of $50 \times$ ), Figure S3: Polarized optical microscope images of $0.25 \mathrm{wt} \% \mathrm{MCC}$ and $\alpha$-cellulose suspension in ChCl:GLY at $60^{\circ} \mathrm{C}$ after $48 \mathrm{~h}$ of shaking (magnification of 50×), Figure S4: Images obtained by optical microscopy of $5 \mathrm{wt} \%$ and $25 \mathrm{wt} \%$ lignin mass fractions in ES at heating rate of $1{ }^{\circ} \mathrm{C} \cdot \mathrm{min}^{-1}$ (magnification of $50 \times$ ), Figure S5: Images obtained by optical microscopy of $5 \mathrm{wt} \%$ and $25 \mathrm{wt} \%$ lignin mass fractions in ES at heating rate of $1^{\circ} \mathrm{C} \cdot \mathrm{min}^{-1}$ (magnification of $50 \times$ ), Figure S6: Images obtained by optical microscopy of $5 \mathrm{wt} \%$ and $25 \mathrm{wt} \%$ xylose mass fractions in ChCL:EtGLY and ChCL:PROP at heating rate of $1^{\circ} \mathrm{C} \cdot \mathrm{min}^{-1}$ (magnification of $\left.50 \times\right)$, Figure S7: Images obtained by polarized optical microscopy of $5 \mathrm{wt} \%$ and $25 \mathrm{wt} \%$ xylose mass fractions in ChCL:GLY and ChCL:LAC at heating rate of $1{ }^{\circ} \mathrm{C} \cdot \mathrm{min}^{-1}$ (magnification of $\left.50 \times\right)$, Figure S8: Time and temperature observed for complete dissolution of lignin in ES at heating rate of $1{ }^{\circ} \mathrm{C} \cdot \mathrm{min}^{-1}$, Table S1: ES water content determined by Metrohm 831 Karl Fischer coulometer. Experiments were performed in triplicate. Viscosity and density values are given from literature reports, Table S2: Temperature (and time) required for full dissolution of xylose in ES at different concentrations. In each experiment the sample was heated from 30 to $100{ }^{\circ} \mathrm{C}$ at heating rate of $1{ }^{\circ} \mathrm{C} \cdot \mathrm{min}^{-1}$.

Author Contributions: F.H.B.S. has carried out all the stages of the paper, conceptualization, conception, research, analysis and conclusions, writing, and final review. R.M.D., A.M.d.C.L., J.A.P.C., and M.C.d.C. were involved in the supervision and final review of the paper. All authors participated in the discussion, conception, and design of the paper. All authors have read and agreed to the published version of the manuscript.

Funding: This research was funded by Coordenação de Aperfeiçoamento de Pessoal de Nível Superior-Brasil (CAPES)—Finance Code 001, FAPESP [2014/21252-0], CNPq [169459/2017-9, 200627/2018-0, 310272/2017-3, 140723/2016-1, 169743/2018-7] and FCT Ref. UIDB/50011/2020 \& UIDP/50011/2020.

Acknowledgments: The authors would like to thank Coordenação de Aperfeiçoamento de Pessoal de Nível Superior-Brasil (CAPES)—Finance Code 001, FAPESP [2014/21252-0], CNPq [169459/2017-9, 200627/2018-0, 310272/2017-3, 140723/2016-1, 169743/2018-7] and FAEPEX/UNICAMP for financial support. This work was also developed within the scope of the project CICECO-Aveiro Institute of Materials, FCT Ref. UIDB/50011/2020 and UIDP/50011/2020, financed by national funds through the FCT/MCTES.

Conflicts of Interest: The authors declare no conflict of interest. 


\section{References}

1. Kan, T.; Strezov, V.; Evans, T.J. Lignocellulosic biomass pyrolysis: A review of product properties and effects of pyrolysis parameters. Renew. Sustain. Energy Rev. 2016, 57, 1126-1140. [CrossRef]

2. Dahmen, N.; Lewandowski, I.; Zibek, S.; Weidtmann, A. Integrated lignocellulosic value chains in a growing bioeconomy: Status quo and perspectives. GCB Bioenergy 2019, 11, 107-117. [CrossRef]

3. Gillet, S.; Aguedo, M.; Petitjean, L.; Morais, A.R.C.; Da Costa Lopes, A.M.; Łukasik, R.M.; Anastas, P.T. Lignin transformations for high value applications: Towards targeted modifications using green chemistry. Green Chem. 2017, 19, 4200-4233. [CrossRef]

4. Mei, Q.; Shen, X.; Liu, H.; Han, B. Selectively transform lignin into value-added chemicals. Chin. Chem. Lett. 2019, 30, 15-24. [CrossRef]

5. Van Haveren, J.; Scott, E.L.; Sanders, J. Bulk chemicals from biomass Jacco. Biofuels Bioprod. Biorefining 2008, 2, 41-57. [CrossRef]

6. Brebu, M.; Vasile, C. Thermal degradation of lignin-a review. Cell. Chem. Technol. 2010, 44, 353-363.

7. Higuchi, T. Microbial degradation of lignin: Role of lignin peroxidase, manganese peroxidase, and laccase. Proc. Jpn. Acad. 2004, 80, 204-214. [CrossRef]

8. Bugg, T.D.H.; Ahmad, M.; Hardiman, E.M.; Rahmanpour, R. Pathways for degradation of lignin in bacteria and fungi. Nat. Prod. Rep. 2011, 28, 1883-1896. [CrossRef]

9. Chen, H. Biotechnology of Lignocellulose Materials, 1st ed.; Chemical Industry Press: Beijing, China, 2014; Volume 218419139, ISBN 9789400768970.

10. Gandini, A.; Belgacem, M.N. Lignins as components of macromolecular materials. In Monomers, Polymers and Composites from Renewable Resources; Elsevier: Amsterdam, The Netherlands, 2008; pp. 243-271.

11. Humbird, D.; Davis, R.; Tao, L.; Kinchin, C.; Hsu, D.; Aden, A.; Schoen, P.; Lukas, J.; Olthof, B.; Worley, M.; et al. Process Design and Economics for Biochemical Conversion of Lignocellulosic Biomass to Ethanol: Dilute-Acid Pretreatment and Enzymatic Hydrolysis of Corn Stover. Natl. Renew. Energy Lab. 2011, 1-147. [CrossRef]

12. Mbous, Y.P.; Hayyan, M.; Hayyan, A.; Wong, W.F.; Hashim, M.A.; Looi, C.Y. Applications of deep eutectic solvents in biotechnology and bioengineering_Promises and challenges. Biotechnol. Adv. 2017, 35, 105-134. [CrossRef]

13. Guthrie, F. LII. On eutexia. Lond. Edinb. Dublin Philos. Mag. J. Sci. 1884, 17, 462-482. [CrossRef]

14. Abbott, A.P.; Capper, G.; Davies, D.L.; Rasheed, R.K.; Tambyrajah, V. Novel Solvent Properties of Choline Cholride Urea Mixtures. Chem. Commun. 2003, 1, 70-71. [CrossRef] [PubMed]

15. Smith, E.L.; Abbott, A.P.; Ryder, K.S. Deep Eutectic Solvents (DESs) and Their Applications. Chem. Rev. 2014, 114, 11060-11082. [CrossRef] [PubMed]

16. Martins, M.A.R.; Pinho, S.P.; Coutinho, J.A.P. Insights into the Nature of Eutectic and Deep Eutectic Mixtures. J. Solution Chem. 2018, 1-3. [CrossRef]

17. Abbott, A.P.; Boothby, D.; Capper, G.; Davies, D.L.; Rasheed, R. Deep Eutectic Solvents Formed Between Choline Chloride and Carboxylic Acids. J. Am. Chem. Soc. 2004, 126, 9142. [CrossRef]

18. Gorke, J.; Srienc, F.; Kazlauskas, R. Toward advanced ionic liquids. Polar, enzyme-friendly solvents for biocatalysis. Biotechnol. Bioprocess Eng. 2010, 15, 40-53. [CrossRef]

19. Zhang, Q.; Benoit, M.; Dea Oliveiraa Vigier, K.; Barrault, J.; Jérǒme, F. Green and inexpensive choline-derived solvents for cellulose decrystallization. Chem. A Eur. J. 2012, 18, 1043-1046. [CrossRef]

20. Bagh, F.S.G.; Shahbaz, K.; Mjalli, F.S.; Hashim, M.A.; AlNashef, I.M. Zinc (II) chloride-based deep eutectic solvents for application as electrolytes: Preparation and characterization. J. Mol. Liq. 2015, 204, 76-83. [CrossRef]

21. Abo-Hamad, A.; Hayyan, M.; AlSaadi, M.A.H.; Mirghani, M.E.S.; Hashim, M.A. Functionalization of carbon nanotubes using eutectic mixtures: A promising route for enhanced aqueous dispersibility and electrochemical activity. Chem. Eng. J. 2017, 311, 326-339. [CrossRef]

22. Gu, L.; Huang, W.; Tang, S.; Tian, S.; Zhang, X. A novel deep eutectic solvent for biodiesel preparation using a homogeneous base catalyst. Chem. Eng. J. 2015, 259, 647-652. [CrossRef]

23. Morrison, H.G.; Sun, C.C.; Neervannan, S. Characterization of thermal behavior of deep eutectic solvents and their potential as drug solubilization vehicles. Int. J. Pharm. 2009, 378, 136-139. [CrossRef]

24. Francisco, M.; van den Bruinhorst, A.; Kroon, M.C. New natural and renewable low transition temperature mixtures (LTTMs): Screening as solvents for lignocellulosic biomass processing. Green Chem. 2012, 14, 2153. [CrossRef] 
25. Makoś, P.; Słupek, E.; Gębicki, J. Extractive detoxification of feedstocks for the production of biofuels using new hydrophobic deep eutectic solvents-Experimental and theoretical studies. J. Mol. Liq. 2020, 308, 113101. [CrossRef]

26. Tian, D.; Guo, Y.; Hu, J.; Yang, G.; Zhang, J.; Luo, L.; Xiao, Y.; Deng, S.; Deng, O.; Zhou, W.; et al. Acidic deep eutectic solvents pretreatment for selective lignocellulosic biomass fractionation with enhanced cellulose reactivity. Int. J. Biol. Macromol. 2020, 142, 288-297. [CrossRef] [PubMed]

27. Procentese, A.; Johnson, E.; Orr, V.; Garruto Campanile, A.; Wood, J.A.; Marzocchella, A.; Rehmann, L. Deep eutectic solvent pretreatment and subsequent saccharification of corncob. Bioresour. Technol. 2015, 192, 31-36. [CrossRef]

28. Xu, G.C.; Ding, J.C.; Han, R.Z.; Dong, J.J.; Ni, Y. Enhancing cellulose accessibility of corn stover by deep eutectic solvent pretreatment for butanol fermentation. Bioresour. Technol. 2016, 203, 364-369. [CrossRef] [PubMed]

29. Kumar, A.K.; Parikh, B.S.; Pravakar, M. Natural deep eutectic solvent mediated pretreatment of rice straw: Bioanalytical characterization of lignin extract and enzymatic hydrolysis of pretreated biomass residue. Environ. Sci. Pollut. Res. 2016, 23, 9265-9275. [CrossRef]

30. Alvarez-Vasco, C.; Ma, R.; Quintero, M.; Guo, M.; Geleynse, S.; Ramasamy, K.K.; Wolcott, M.; Zhang, X. Green Chemistry Cutting-edge research for a greener sustainable future Unique low-molecular-weight lignin with high purity extracted from wood by deep eutectic solvents (DES): A source of lignin for valorization Unique low-molecular-weight lignin with hig. Green Chem. 2016, 18, 5071-5378. [CrossRef]

31. Zhang, C.-W.; Xia, S.-Q.; Ma, P.-S. Facile pretreatment of lignocellulosic biomass using deep eutectic solvents. Bioresour. Technol. 2016, 219, 1-5. [CrossRef] [PubMed]

32. Jablonský, M.; Škulcová, A.; Malvis, A.; Šima, J. Extraction of value-added components from food industry based and agro-forest biowastes by deep eutectic solvents. J. Biotechnol. 2018, 282, 46-66. [CrossRef]

33. Soares, B.; Tavares, D.J.P.; Amaral, J.L.; Silvestre, A.J.D.; Freire, C.S.R.; Coutinho, J.A.P. Enhanced Solubility of Lignin Monomeric Model Compounds and Technical Lignins in Aqueous Solutions of Deep Eutectic Solvents. ACS Sustain. Chem. Eng. 2017, 5, 4056-4065. [CrossRef]

34. Lynam, J.G.; Kumar, N.; Wong, M.J. Deep eutectic solvents' ability to solubilize lignin, cellulose, and hemicellulose; thermal stability; and density. Bioresour. Technol. 2017, 238, 684-689. [CrossRef] [PubMed]

35. Hou, X.-D.; Feng, G.-J.; Ye, M.; Huang, C.-M.; Zhang, Y. Significantly enhanced enzymatic hydrolysis of rice straw via a high-performance two-stage deep eutectic solvents synergistic pretreatment. Bioresour. Technol. 2017, 238, 139-146. [CrossRef] [PubMed]

36. Soares, B.; Silvestre, A.J.D.; Rodrigues Pinto, P.C.; Freire, C.S.R.; Coutinho, J.A.P. Hydrotropy and Cosolvency in Lignin Solubilization with Deep Eutectic Solvents. ACS Sustain. Chem. Eng. 2019. [CrossRef]

37. Sharma, M.; Mukesh, C.; Mondal, D.; Prasad, K. Dissolution of $\alpha$-chitin in deep eutectic solvents. RSC Adv. 2013, 3, 18149. [CrossRef]

38. Morais, E.S.; Mendonåa, P.V.; Coelho, J.F.J.; Freire, M.G.; Freire, C.S.R.; Coutinho, J.A.P.; Silvestre, A.J.D. Deep Eutectic Solvent Aqueous Solutions as Efficient Media for the Solubilization of Hardwood Xylans. ChemSusChem 2018, 1-11. [CrossRef]

39. Ji, H.; Lv, P. Mechanistic insights into the lignin dissolution behaviors of a recyclable acid hydrotrope, deep eutectic solvent (DES), and ionic liquid (IL). Green Chem. 2020, 22, 1378-1387. [CrossRef]

40. Balaji, C.; Banerjee, T.; Goud, V.V. COSMO-RS based predictions for the extraction of lignin from lignocellulosic biomass using ionic liquids: Effect of cation and anion combination. J. Solut. Chem. 2012, 41, 1610-1630. [CrossRef]

41. Casas, A.; Palomar, J.; Alonso, M.V.; Oliet, M.; Omar, S.; Rodriguez, F. Comparison of lignin and cellulose solubilities in ionic liquids by COSMO-RS analysis and experimental validation. Ind. Crops Prod. 2012, 37, 155-163. [CrossRef]

42. Jeliński, T.; Cysewski, P. Application of a computational model of natural deep eutectic solvents utilizing the COSMO-RS approach for screening of solvents with high solubility of rutin. J. Mol. Model. 2018, 24, 1-17. [CrossRef]

43. Swatloski, R.P.; Spear, S.K.; Holbrey, J.D.; Rogers, R.D. Dissolution of cellose with ionic liquids. J. Am. Chem. Soc. 2002, 124, 4974-4975. [CrossRef] [PubMed]

44. Pu, Y.; Jiang, N.; Ragauskas, A.J. Ionic liquid as a green solvent for lignin. J. Wood Chem. Technol. 2007, 27, 23-33. [CrossRef]

45. Fitzpatrick, M.; Champagne, P.; Cunningham, M.F.; Falkenburger, C. Application of optical microscopy as a screening technique for cellulose and lignin solvent systems. Can. J. Chem. Eng. 2012, 90, 1142-1152. [CrossRef] 
46. Zavrel, M.; Bross, D.; Funke, M.; Büchs, J.; Spiess, A.C. High-throughput screening for ionic liquids dissolving (ligno-)cellulose. Bioresour. Technol. 2009, 100, 2580-2587. [CrossRef] [PubMed]

47. Andanson, J.M.; Bordes, E.; Devémy, J.; Leroux, F.; Pádua, A.A.H.; Gomes, M.F.C. Understanding the role of co-solvents in the dissolution of cellulose in ionic liquids. Green Chem. 2014, 16, 2528-2538. [CrossRef]

48. Dias, R.M.; Sosa, F.H.B.; da Costa, M.C. Dissolution of lignocellulosic biopolymers in ethanolamine-Based protic ionic liquids. Polym. Bull. 2019. [CrossRef]

49. Prausnitz, J.M.; Lichtenthaler, R.N.; de Azevedo, E.G. Molecular Thermodynamics of Fluid-Phase Equilibria; Pearson Education: London, UK, 1998; ISBN 9780132440509.

50. Dadi, A.P.; Varanasi, S.; Schall, C.A. Enhancement of cellulose saccharification kinetics using an ionic liquid pretreatment step. Biotechnol. Bioeng. 2006, 95, 904-910. [CrossRef]

51. Pillai, C.K.S.; Paul, W.; Sharma, C.P. Chitin and chitosan polymers: Chemistry, solubility and fiber formation. Prog. Polym. Sci. 2009, 34, 641-678. [CrossRef]

52. Verma, C.; Mishra, A.; Chauhan, S.; Verma, P.; Srivastava, V.; Quraishi, M.A.; Ebenso, E.E. Dissolution of cellulose in ionic liquids and their mixed cosolvents: A review. Sustain. Chem. Pharm. 2019, 13, 100162. [CrossRef]

53. Mayer, C.; Moritz, R.; Kirschner, C.; Borchard, W.; Maibaum, R.; Wingender, J.; Flemming, H.C. The role of intermolecular interactions: Studies on model systems for bacterial biofilms. Int. J. Biol. Macromol. 1999, 26, 3-16. [CrossRef]

54. Mahkam, M. Starch-based polymeric carriers for oral-insulin delivery. J. Biomed. Mater. Res. Part A 2010, 92, 1392-1397. [CrossRef] [PubMed]

55. Zhao, H.; Baker, G.A.; Song, Z.; Olubajo, O.; Crittle, T.; Peters, D. Designing enzyme-compatible ionic liquids that can dissolve carbohydrates. Green Chem. 2008, 10, 696-705. [CrossRef]

56. Xu, A.; Wang, J.; Wang, H. Effects of anionic structure and lithium salts addition on the dissolution of cellulose in 1-butyl-3-methylimidazolium-based ionic liquid solvent systems. Green Chem. 2010, 12, 268-275. [CrossRef]

57. Zhang, H.; Wu, J.; Zhang, J.; He, J. 1-allyl-3-methylimidazolium chloride room temperature ionic liquid: A new and powerful nonderivatizing solvent for cellulose. Macromolecules 2005, 38, 8272-8277. [CrossRef]

58. Xun, Y.C.; You, Z.T.; Xu, F. Deep eutectic solvents (DESs) for cellulose dissolution: A mini-review. Cellulose 2019, 26, 205-213.

59. Wahlström, R.; Hiltunen, J.; Mariah, P.d.S.N.S.; Kruus, S.V.; Kruus, K. Comparison of three deep eutectic solvents and 1-ethyl-3-methylimidazolium acetate in the pretreatment of lignocellulose: Effect on enzyme stability, lignocellulose digestibility and one-pot hydrolysis. RSC Adv. 2016, 6, 68100-68110. [CrossRef]

60. Häkkinen, R.; Abbott, A. Solvation of carbohydrates in five choline chloride-based deep eutectic solvents and the implication for cellulose solubility. Green Chem. 2019, 21, 4673-4682. [CrossRef]

61. Dobbs, W.; Douce, L.; Allouche, L.; Louati, A.; Malbosc, F.; Welter, R. New ionic liquid crystals based on imidazolium salts. New J. Chem. 2006, 30, 528-532. [CrossRef]

62. Malaeke, H.; Housaindokht, M.R.; Monhemi, H.; Izadyar, M. Deep eutectic solvent as an efficient molecular liquid for lignin solubilization and wood delignification. J. Mol. Liq. 2018, 263, 193-199. [CrossRef]

63. Liu, Y.; Chen, W.; Xia, Q.; Guo, B.; Wang, Q.; Liu, S.; Liu, Y.; Li, J.; Yu, H. Efficient Cleavage of Lignin-Carbohydrate Complexes and Ultrafast Extraction of Lignin Oligomers from Wood Biomass by Microwave-Assisted Treatment with Deep Eutectic Solvent. ChemSusChem 2017, 10, 1692-1700. [CrossRef]

64. Melro, E.; Alves, L.; Antunes, F.E.; Medronho, B. A brief overview on lignin dissolution. J. Mol. Liq. 2018, 265, 578-584. [CrossRef]

(C) 2020 by the authors. Licensee MDPI, Basel, Switzerland. This article is an open access article distributed under the terms and conditions of the Creative Commons Attribution (CC BY) license (http://creativecommons.org/licenses/by/4.0/). 